\title{
Comparison of functional efficacy of surfactant protein B analogues in lavaged rats
}

\author{
M. Gupta, J.M. Hernández-Juviel, A.J. Waring, R. Bruni, F.J. Walther
}

\begin{abstract}
Comparison of functional efficacy of surfactant protein $B$ analogues in lavaged rats. $M$. Gupta, J.M. Hernández-Juviel, A.J. Waring, R. Bruni, F.J. Walther. (C)ERS Journals Ltd 2000.

ABSTRACT: Leakage of plasma proteins into the alveoli inhibits pulmonary surfactant function and worsens respiratory failure. Surfactant protein B (SP-B), is essential for surfactant function, but the N-terminal domain of human SP-B (residues $1.25, \mathrm{SP}^{-\mathrm{B}^{1-25}}$ ) can mimic the biophysical properties of full length SP-B ${ }^{1-78}$ in vitro. The authors compared the function and inhibition resistance of synthetic surfactant preparations containing SP-B analogues to a natural bovine surfactant preparation "Survanta ${ }^{\mathrm{TM}}$ ".

Eight groups of eight rats were lavaged to induce surfactant deficiency, fibrinogen was instilled as a surfactant inhibitor, and then they were rescued with exogenous surfactant. Five experimental surfactants were formulated by mixing $3 \%$ SP-B ${ }^{\text {P-78 }}$, or an equimolar amount of SP-B ${ }^{1-25}$ and/or $1 \%$ palmitoylated surfactant protein C (SPC) ${ }^{1-35}$, into a standard phospholipid (PL) mixture: $\mathbf{B}^{1-78}, \mathbf{B}^{1-25}, C^{1-35}, \mathbf{B}^{1-78}+C^{1-35}$, and $B^{1-25}+C^{1-35}$ surfactant preparations. Survanta ${ }^{T M}$ was used as a positive control and PL and no treatment as a negative control. Lung function was assessed during a 2$h$ period using arterial blood gas and lung compliance measurements.

Rats treated with $\mathrm{B}^{1-25}+\mathrm{C}^{1-35}$ surfactant and Survanta ${ }^{\mathrm{TM}}$ maintained the highest oxygenation and lung compliance values throughout the experiments. The surfactants could be ranked as $B^{1-25}+C^{1-35}$ surfactant and Survanta ${ }^{M}>B^{1-25}$ and $B^{1-78}+C^{1-35}$ surfactants $>$ others.

Because the N-terminal domain of surfactant protein $B^{1-25}$ can improve inhibition resistance, it may be able to substitute for surfactant protein $B$ in exogenous surfactant preparations.
\end{abstract}

Eur Respir J 2000; 16: 1129-1133.
Pulmonary surfactant is a complex mixture of lipids and four surfactant proteins (SP-A, B, C, and D). Among the surfactant proteins, only the two small hydrophobic proteins SP-B and SP-C are biophysically active. SP-B is essential for surfactant function as inherited SP-B deficiency is lethal in newborn infants [1] and antibodies against SP-B cause respiratory distress syndrome (RDS) in vivo [2]. RDS in premature infants is caused by lung immaturity and surfactant deficiency. Pulmonary surfactant function can also be inhibited by plasma proteins, which invade the alveolar space during acute lung injury [3]. Intra-alveolar accumulation of plasma proteins is common to adult RDS (ARDS), in which acute lung injury increases endothelial and epithelial permeability [4] and proteins enter the alveolar space in rough proportion to their plasma concentration [5]. Surfactant inhibition plays an important role in surfactant dysfunction and development of ARDS. The rank order of potency of plasma proteins for surfactant inhibition is fibrin monomer $>$ fibrinogen $>$ haemoglobin $>$ albumin $[6-$ 11]. Supplementation of surfactant may allow recovery of surfactant function under conditions of inhibition [12].

Advancements in peptide synthesis have opened up the possibility of designing SP-B and SP-C mimics, which are
Harbor-(University of California) Research and Education Institute, Torrance \& Dept of Pediatrics, Charles R. Drew University of Medicine \& Science, Los Angeles, CA, USA.

\section{Correspondence: F.J. Walther}

Harbor-UCLA Research and Education Institute

1124 West Carson Street

Research Building 1, Torrance

CA 90502

USA

Fax: 13103207749

Keywords: Respiratory distress syndrome surfactant

surfactant inhibition

surfactant proteins

synthetic surfactant peptides

Received: March 62000

Accepted after revision August 252000

This study was supported by grant HL55534 from the National Institutes of Health (Bethesda, MD, USA) not only functionally active but also confer resistance against surfactant inhibition [13]. The synthetic surfactant peptide SP-B ${ }^{1-25}$, based on the N-terminal domain of the human surfactant protein $\mathrm{B}$ sequence (residues 1.25), mimics the biophysical properties of full length SP-B ${ }^{1-78}$ peptide in a synthetic surfactant preparation in vitro [1417]. Synthesizing and formulating a short 25-residue peptide has practical advantages over the production of a full-length 78-residue peptide and has encouraged the authors to study SP-B ${ }^{1-25}$ in vivo. The function and inhibition resistance of these synthetic SP-B peptides was investigated, in combination with full length, palmitoylated SP-C ${ }^{1-35}$ peptide, in a ventilated surfactant-deficient rat model in which surfactant inhibition was induced by intratracheal administration of human fibrinogen.

\section{Methods}

\section{Overview}

Eight groups of eight rats were lavaged until surfactantdeficient (oxygen tension in arterial blood $\left(\mathrm{Pa}_{\mathrm{a}} \mathrm{O}_{2}\right)<100$ $\mathrm{mmHg}$ ), followed by intratracheal administration of 
human fibrinogen to induce inhibition of residual surfactant, and then rescued with one of six synthetic surfactant preparations, Survanta $^{\mathrm{TM}}$, or alternatively were not treated with surfactant (NT). The synthetic surfactants were prepared by mixing $3 \%$ of the full-length $\mathrm{SP}^{1-78}$ or an equimolar amount of SP-B ${ }^{1-25}$ peptide and/or $1 \%$ of the palmitoylated SP-C ${ }^{1-35}$ into a standard phospholipid mixture (PL). In addition to PL alone, five experimental preparations were created: $\mathrm{PL}+\mathrm{SP}-\mathrm{B}^{1-25}\left(\mathrm{~B}^{1-25}\right.$ surfactant $)$, PL+SP-B ${ }^{1-78}\left(B^{1-78}\right.$ surfactant $), P L+1 \%$ SP-C ${ }^{1-35}\left(C^{1-35}\right.$ surfactant), PL+SP-B ${ }^{1-25}+$ SP-C $C^{1-35}\left(\mathrm{~B}^{1-25}+\mathrm{C}^{1-35}\right.$ surfactant) and PL+SP-B ${ }^{1-78}+$ SP-C $C^{1-35}\left(\mathrm{~B}^{1-78}+\mathrm{C}^{1-35}\right.$ surfactant $)$. Survanta ${ }^{\mathrm{TM}}$ was used as a positive control and PL surfactant alone and NT as negative controls. Lung function was assessed using arterial blood gas and dynamic compliance measurements. After $2 \mathrm{~h}$ of ventilation, pressure volume curves were performed and the lungs relavaged for measurement of protein and phospholipid recovery.

\section{Synthesis, purification, and formulation of surfactant peptides}

Full length SP-B ${ }^{1-78}$, N-terminal SP-B ${ }^{1-25}$, and palmitoylated SP-C ${ }^{1-35}$, were each synthesized on a $0.25-\mathrm{mM}$ scale with an Applied Biosystems Model 431A peptide synthesizer (Foster City, CA, USA) using a FastMoc ${ }^{\mathrm{TM}}$ strategy [18]. The peptides were synthesized with prederivatized Fmoc-Gly (Calbiochem-Nova, La Jolla, CA, USA) or PEG-PA resins (Perceptive Biosystems, Old Connecticut Path, MA, USA) and were single coupled for all residues. Purification of crude peptide product was carried out by reverse-phase high performance liquid chromatography. The molecular mass of the peptides was confirmed by fast atom bombardment mass spectroscopy or electrospray mass spectroscopy.

The full-length SP-B ${ }^{1-78}$ peptide was based on the 78 residue human SP-B sequence $[19,20]$, the SP-B ${ }^{1-25}$ peptide on the N-terminal of human SP-B with one modification, cysteine in position 11 was replaced by alanine (Cys-11 >Ala-11 variant monomer) [14-17, 21]. The SP-C ${ }^{1-35}$ peptide was based on the human SP-C sequence and palmitoylated as reported previously [20, $22]$. The present study group has described conformation of the structure of these peptides $[21,22]$.

The synthetic surfactants were formulated by cosolvating the peptide (SP-B ${ }^{1-78} 3 \mathrm{wt} \%$ and SP-C ${ }^{1-35} 1$ wt $\%$ ) with a standard PL mixture consisting of dipalmitoyl phosphatidylcholine, 1-palmitoyl-2-oleoyl phosphatidylglycerol, and palmitic acid (69:22:9, wt:wt:wt) [19]. SP$\mathrm{B}^{1-25}$ was co-solvated at amounts equimolar to SP-B ${ }^{1-78}$. The bovine surfactant Survanta ${ }^{\mathrm{TM}}$ (Ross Laboratories, Columbus, OH, USA), containing PL with $\sim 0.8 \%$ SP-B/ $\mathrm{C}$ [23], was used as a standard. All surfactant preparations were prepared at a concentration of $25 \mathrm{mg} \mathrm{PL} \cdot \mathrm{mL}^{-1}$ and administered in a dose of $100 \mathrm{mg} \mathrm{PL} \cdot \mathrm{kg}^{-1}$ body weight.

\section{In vitro surface activity}

Changes in surface tension were measured during compression on unbuffered $0.9 \% \mathrm{NaCl}$ at room temperature in a modified Langmuir-Wilhelmy balance (KimRay, Greenfield Surfactometer, Oklahoma City, OK, USA) [16, 24]. Samples containing $50 \mu \mathrm{g}$ of phospholipids were loaded on a saline subphase in a $51.5 \mathrm{~cm}^{2}$ rectangular Teflon trough. Compression of the surface film from $100 \%$ to $20 \%$ of the total area was carried out with a cycle time of $90 \mathrm{~s}$. In vitro inhibition resistance of the synthetic surfactants and Survanta ${ }^{\mathrm{TM}}$ was tested by placing $5 \mu \mathrm{g}$ of fibrinogen $\left(5 \mu \mathrm{L}\right.$ of $1 \mathrm{mg}$ fibrinogen $\left.\cdot \mathrm{mL}^{-1}\right)$ on the surface balance and, after the completion of three compression cycles, surfactant samples containing $50 \mu \mathrm{g}$ of PL were loaded on the surface balance, followed by four more compression cycles. The fibrinogen/phospholipid ratio $(1: 10)$ was the same as that used in the in vivo studies.

\section{Animal protocol}

The animal experiments were approved by the HarborUCLA Research and Education Institute Animal Care and Use Committee. The anaesthetic and surgical methods used in the study were the same as previously described $[20,22]$. Briefly, adult male Sprague-Dawley rats were anaesthetized, intubated and ventilated with a rodent ventilator (Harvard Apparatus, South Natick, MA, USA) with $100 \%$ oxygen, a tidal volume of $7.5 \mathrm{~mL} \cdot \mathrm{kg}^{-1}$ and a rate of $60 \cdot \mathrm{min}^{-1}$. An arterial line was placed, the rats were paralysed and then transferred to a plethysmograph consisting of a Plexiglas box. Airway pressures were measured with a pressure transducer (Gould Inc, Cleveland, OH, USA) and tidal volume with a pneumotachometer (Validyne, Northridge, CA, USA) connected to a multichannel recorder (Gould Inc, Cleveland, $\mathrm{OH}$, USA). The lungs were lavaged $8-12$ times with $8 \mathrm{~mL}$ of $0.9 \% \mathrm{NaCl}$. After the $\mathrm{Pa}, \mathrm{O}_{2}$ in $100 \%$ oxygen had reached stable values of $<100 \mathrm{mmHg}$ (time $=-15 \mathrm{~min}$ ), the rats were treated by instilling $10 \mathrm{mg} \cdot \mathrm{kg}^{-1}$ of human fibrinogen, followed by $100 \mathrm{mg} \cdot \mathrm{kg}^{-1}$ of surfactant $15 \mathrm{~min}$ later (time $=0 \mathrm{~min}$ ). Arterial blood gases, tidal volume, and airway pressures were determined at 15 min intervals throughout the experiments. After $2 \mathrm{~h}$ of ventilation, the rats were killed, exsanguinated and the lungs degassed in situ. A pressure-volume curve was measured in situ in each pair of rat lungs to define lung mechanics and the lungs were relavaged three times with $8 \mathrm{~mL}$ of $0.9 \%$ $\mathrm{NaCl}$. Each treatment group consisted of eight animals.

\section{Lung lavages}

The first three lung lavages of each rat, performed to induce surfactant deficiency (initial lavage), and the three lung lavages performed at the end of the experiment (post mortem lavage) were each pooled. Protein content of the lung lavages was measured with a modified Lowry assay [25]. PL content of the lung lavages was determined by phosphorus measurement following chloroform:methanol extraction [26].

\section{Data presentation and statistics}

In vitro surface activity of the various surfactants under standard conditions and after fibrinogen inhibition is presented using the averaged last curves with a minimum of four measures for each data point. Oxygenation is reported using $\mathrm{Pa}, \mathrm{O}_{2}$. Dynamic lung compliance was calculated by dividing tidal volume $\cdot \mathrm{kg}$ body weight ${ }^{-1}$ by changes in airway pressure (peak inspiratory pressure minus positive end-expiratory pressure) $\left(\mathrm{mL} \cdot \mathrm{kg}^{-}-\mathrm{cmH}_{2} \mathrm{O}\right)$. Protein and 
PL recovery $\left(\mathrm{mg} \cdot \mathrm{kg}^{-1}\right)$ was calculated using the protein and PL content of the lung lavage material divided by body weight $\left(\mathrm{mg}\right.$ protein $\left.\cdot \mathrm{kg}^{-1}\right)$. Oxygenation and dynamic compliance data are given as mean \pm SD with eight rats in each experimental group. Between-group comparisons were performed by one-way analysis of variance followed by the Student-Newman-Keuls multiple comparison procedure. An unpaired t-test was used for comparisons versus control values. A p-value $\leq 0.05$ was considered to indicate a significant difference.

\section{Results}

Rats treated with $\mathrm{B}^{1-25}+\mathrm{C}^{1-35}$ surfactant and Survanta ${ }^{\mathrm{TM}}$ reached the highest oxygenation values, with intermediate values for $\mathrm{B}^{1-25}$ and $\mathrm{B} 1^{1-78} \mathrm{C}^{1-35}$ surfactant, and the lowest values for $\mathrm{B}^{1-78}, \mathrm{C}^{1-35}$, and PL surfactant (fig. 1). Dynamic compliance values during mechanical ventilation (fig. 2) and post mortem lung volumes were highest for rats treated with $\mathrm{B}^{1-25}+\mathrm{C}$ surfactant and Survanta ${ }^{\mathrm{TM}}$, followed by those treated with $\mathrm{B}^{1-25}$ and $\mathrm{B}^{1-78}+\mathrm{C}^{1-35}$ surfactant. Rats treated with $\mathrm{B}^{1-78}, \mathrm{C}^{1-35}$, and PL surfactant had dynamic compliance values and post mortem lung volumes, which were intermediate between these four groups and the NT group. The in vivo activity of the surfactant preparations could therefore, be ranked as follows: $\mathrm{B}^{1-25}+\mathrm{C}^{1-35}$ surfactant and Survanta ${ }^{\mathrm{TM}}>\mathrm{B}^{1-25}$ and $\mathrm{B}^{1-78}+\mathrm{C}^{1-35}$ surfactant $>\mathrm{B}^{1-78}, \mathrm{C}^{1-35}$, and PL surfactant $>$ NT.

Protein recovery, a marker of acute lung injury, was about 10 times higher in the post mortem than in the initial lavages $(\mathrm{p}<0.001)$ (table 1$)$. In the post mortem lavages, protein recovery was highest in the NT group and lowest in the Survanta ${ }^{T M}$ group $(\mathrm{p}<0.05)$. PL recovery in the post mortem lavages of the surfactant treatment groups was higher than in the initial lavages and indicated that $~ 15 \%$ of the instilled surfactant was recovered during the post mortem lavages (table 1). The NT group had PL recovery values in the post mortem lavages, which were

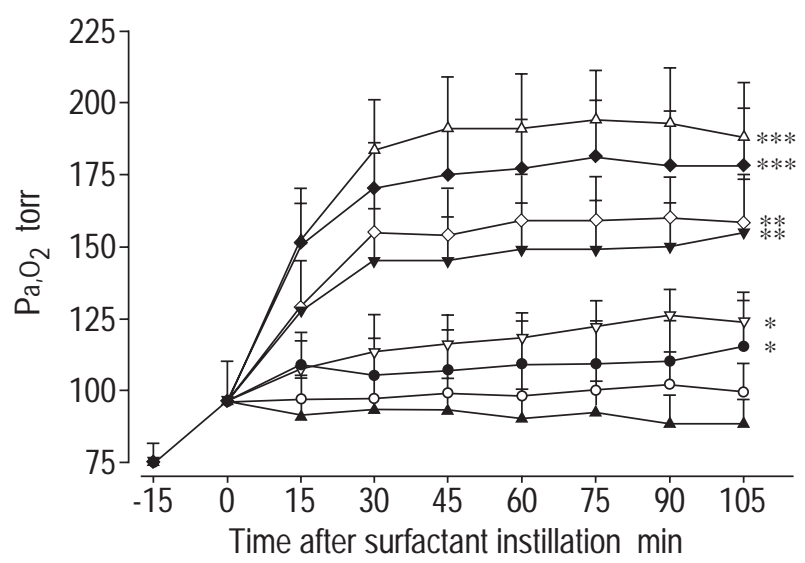

Fig. 1. - Mean \pm standard deviation oxygen tension in arterial blood $\left(P \mathrm{a}, \mathrm{O}_{2}\right)$ values in ventilated, lavaged rats after intratracheal fibrinogen instillation at $-15 \mathrm{~min}$ and surfactant treatment at $0 \mathrm{~min}$. ***: $\mathrm{p}<0.05$ versus $\mathrm{B}^{1-25}, \mathrm{~B}^{1-78}+\mathrm{C}^{1-35}, \mathrm{~B}^{1-78}, \mathrm{C}^{1-35}$ and phospholipid surfactant and no treatment; **: $\mathrm{p}<0.05$ versus $\mathrm{B}^{1-78}, \mathrm{C}^{1-35}$ and phospholipid surfactant and no treatment; *: $\mathrm{p}<0.05$ versus phospholipid surfactant and no treatment. $\triangle: \mathrm{B}^{1-25}+\mathrm{C} ; \bullet:$ Survanta ${ }^{\mathrm{TM}} ; \diamond: \mathrm{B}^{1-25} ; \nabla: \mathrm{B}^{1-78}+\mathrm{C} ; \nabla:$ $\mathrm{B}^{1-78} ;$

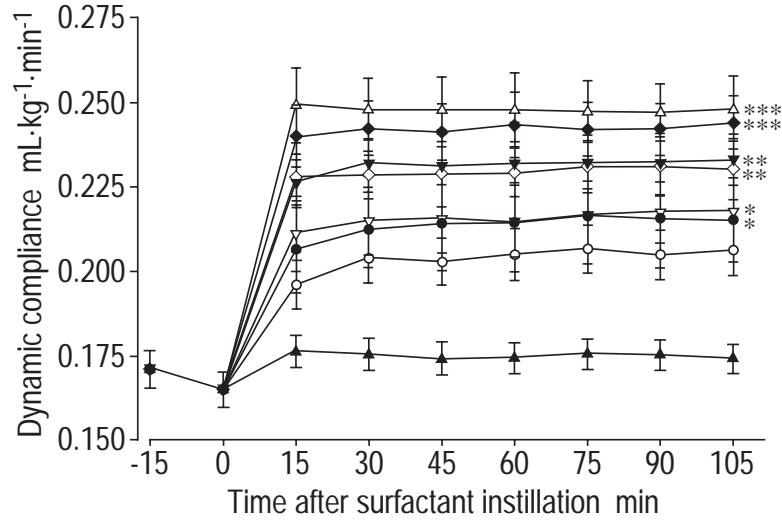

Fig. 2. - Mean \pm standard deviation dynamic compliance values in ventilated, lavaged rats after intratracheal fibrinogen instillation at $-15 \mathrm{~min}$ and surfactant treatment at 0 min. ${ }^{* * *}: \mathrm{p}<0.05$ versus $\mathrm{B}^{1-25}, \mathrm{~B}^{1-78}+$ $\mathrm{C}^{1-35}, \mathrm{~B}^{1-78}, \mathrm{C}^{1-35}$ and phospholipid surfactant and no treatment; **: $\mathrm{p}<0.05$ versus $\mathrm{B}^{1-78}, \mathrm{C}^{1-35}$ and phospholipid surfactant and no treatment; *: $\mathrm{p}<0.05$ versus phospholipid surfactant and no treatment. $\triangle: \mathrm{B}^{1-25}+\mathrm{C} ; \bullet:$ Survanta ${ }^{\mathrm{TM}} ; \diamond: \mathrm{B}^{1-25} ; \nabla: \mathrm{B}^{1-78}+\mathrm{C} ; \nabla: \mathrm{B}^{1-78} ;$ surfactant protein $\mathrm{C} ; \bigcirc$ : phospholipid; $\boldsymbol{\Delta}$ : no treatment.

intermediate between the initial lavage values and the post mortem lavage values of the surfactant groups $(\mathrm{p}<0.05)$.

Under baseline conditions, all surfactant preparations, i.e. $\mathrm{PL}, \mathrm{B}^{1-25}, \mathrm{~B}^{1-78}, \mathrm{C}^{1-35}, \mathrm{~B}^{1-25}+\mathrm{C}^{1-35}, \mathrm{~B}^{1-78}+\mathrm{C}^{1-35}$ and Survanta ${ }^{\mathrm{TM}}$, reached minimum surface tensions $(\gamma \mathrm{min})$ $<10 \mathrm{mN} \cdot \mathrm{m}^{-1}$ on the Wilhelmy balance (fig. 3a). All surfactants reached a $\gamma \mathrm{min}<10 \mathrm{mN} \cdot \mathrm{m}^{-1}$ at compression above $50 \%$ of the surface area, except for $\mathrm{C}^{1-35}$ and PL surfactant, which reached these values only after compression to $40 \%$ and $34 \%$ of the surface area, respectively. The in vitro resistance of the surfactant preparations against fibrinogen inhibition is shown in figure $3 \mathrm{~b} . \mathrm{B}^{1-78}$, $\mathrm{B}^{1-25}, \mathrm{~B}^{1-25}+\mathrm{C}^{1-35}$, and $\mathrm{B}^{1-78}+\mathrm{C}^{1-35}$ surfactants and Survanta ${ }^{\mathrm{TM}}$ reached $\gamma \mathrm{min}<10 \mathrm{mN} \cdot \mathrm{m}^{-1}$, whereas the $\gamma \mathrm{min}$ for $\mathrm{C}^{1-35}$ surfactant was $18 \pm 3 \mathrm{mN} \cdot \mathrm{m}^{-1}$ and for PL surfactant $44 \pm 1 \mathrm{mN} \cdot \mathrm{m}^{-1}$. Under inhibitory conditions, $\mathrm{B}^{1-78}$ reached a $\gamma \min <10 \mathrm{mN} \cdot \mathrm{m}^{-1}$ at $69 \%, \mathrm{~B}^{1-25}+\mathrm{C}^{1-35}$ at $65 \%$, $\mathrm{B}^{1-25}$ at $62 \%, \mathrm{~B}^{1-78}+\mathrm{C}^{1-35}$ at $53 \%$ and Survanta ${ }^{\mathrm{TM}}$ at $22 \%$ surface area (fig. $3 \mathrm{~b}$ ).

Table 1. - Mean \pm SD protein and phospholipid recovery in the initial and final lung lavages of the various surfactant treatment groups

\begin{tabular}{lcc}
\hline Treatment groups & $\begin{array}{c}\text { Protein } \\
\text { recovery } \\
\mathrm{mg} \cdot \mathrm{kg}^{-1}\end{array}$ & $\begin{array}{c}\text { Phospholipid } \\
\text { recovery } \\
\mathrm{mg} \cdot \mathrm{kg}^{-1}\end{array}$ \\
\hline Initial lavage & $24 \pm 3^{*}$ & $7.3 \pm 0.7^{*}$ \\
NT & $308 \pm 64^{*}$ & $11.8 \pm 1.6^{*}$ \\
PL surfactant & $239 \pm 52$ & $24.1 \pm 6.6$ \\
$\mathrm{C}^{1-35}$ surfactant & $228 \pm 38$ & $28.7 \pm 8.9$ \\
$\mathrm{~B}^{1-78}$ surfactant & $234 \pm 63$ & $24.9 \pm 3.9$ \\
$\mathrm{~B}^{1-78}+\mathrm{C}^{1-35}$ surfactant & $229 \pm 50$ & $26.3 \pm 1.6$ \\
$\mathrm{~B}^{1-25}$ surfactant & $234 \pm 56$ & $26.3 \pm 2.1$ \\
Survanta & $156 \pm 21^{*}$ & $29.5 \pm 7.7$ \\
$\mathrm{~B}^{1-25}+\mathrm{C}^{1-35}$ surfactant & $238 \pm 24$ & $25.4 \pm 5.3$ \\
\hline
\end{tabular}

NT: no treatment; PL: phospholipid. $\mathrm{n}=8$ rats per group. *: $\mathrm{p}<0.05$ versus all other groups. 

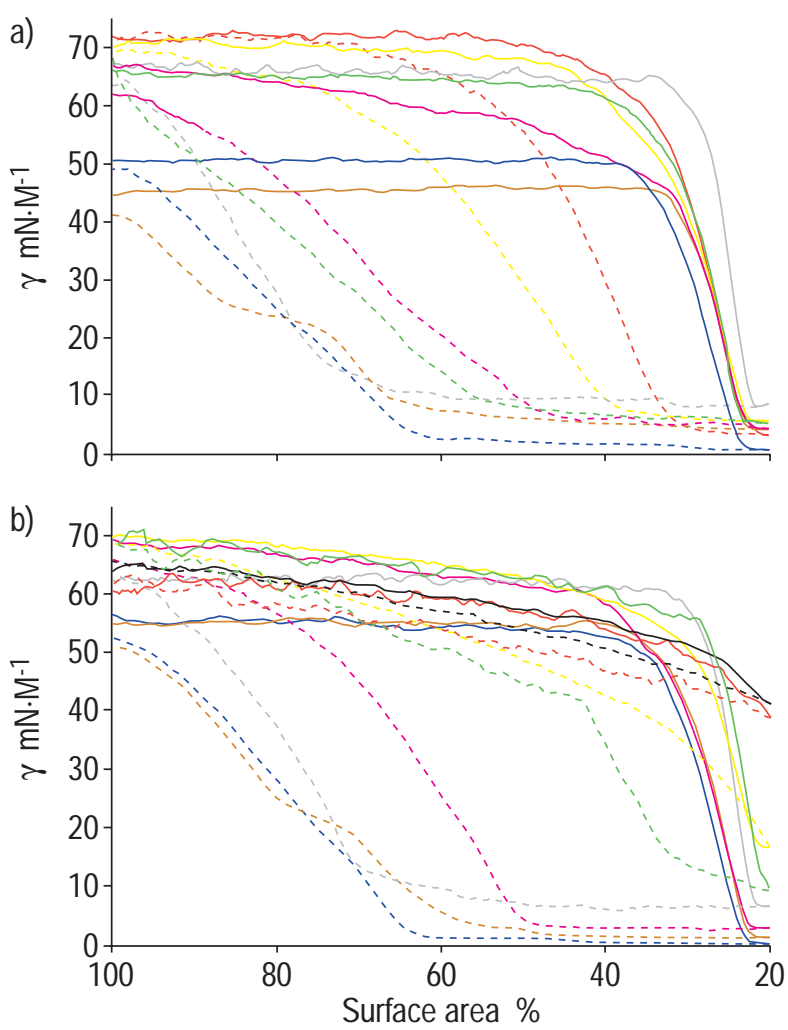

Fig. 3. - In vitro surface activity of the phospholipid, $\mathrm{B}^{1-78}, \mathrm{~B}^{1-25}$, $\mathrm{C}^{1-35}, \mathrm{~B}^{1-78}+\mathrm{C}^{1-35}$ and $\mathrm{B}^{1-25}+\mathrm{C}^{1-35}$ surfactant preparations and the bovine surfactant Survanta ${ }^{\mathrm{TM}}$, tested on a Langmuir-Wilhelmy balance. a) surface tension under baseline conditions; b) surface tension with fibrinogen inhibition. $\gamma$ : surface tension. Compression curves: - - : PL; : Survanta; - - : $\mathrm{B}^{1-78} ;-\ldots: \mathrm{B}^{1-78}+\mathrm{C}^{1-35} ; \quad: \mathrm{C}^{1-35} ;--\mathrm{B}^{1-25} ;---$ $: \mathrm{B}^{1-25}+\mathrm{C}^{1-35} ;---$ : fibrinogen; decompression curves: $\frac{1}{1-25}: \mathrm{PL}^{1-}:$

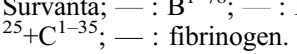

\section{Discussion}

In the surfactant-deficient rat with instilled fibrinogen, rescue treatment with surfactant containing the N-terminal domain of SP-B ( $\mathrm{B}^{1-25}+\mathrm{C}^{1-35}$ surfactant) was equally effective as Survanta ${ }^{\mathrm{TM}}$ in maintaining oxygenation and lung volume. The effect of $\mathrm{B}^{1-78}+\mathrm{C}^{1-35}$ and $\mathrm{B}^{1-25}$ surfactant on lung function was intermediate between that of $\mathrm{B}^{1-25}+\mathrm{C}^{1-35}$ surfactant or Survanta ${ }^{\mathrm{TM}}$ and $\mathrm{B}^{1-78}$ or $\mathrm{C}^{1-35}$ surfactant. These results suggest that the N-terminal domain of SP-B plays an important role in the resistance of surfactant against inhibition by the plasma protein fibrinogen.

The present study investigated the differences between a short and full-length SP-B peptide. Both are based on the human SP-B sequence, but the SP-B ${ }^{1-25}$ peptide (based on the N-terminal of human SP-B) was modified in position 11 by replacing the cysteine with alanine (Cys-11 >Ala-11 variant monomer). This modification was initiated because the original sequence lacked the respreadability of lipids observed with the full-length protein and had some haemolytic activity that was not seen with full length SP-B [14-17, 21]. The relationship between peptide structure, biophysical properties and inhibitory resistance of SP-B/C peptides remains complicated. Measurement of in vitro surface activity has only a limited predictability towards in vivo activity. Surface properties of the SP-B ${ }^{1-78}$ and SP-B ${ }^{1-25}$ peptides (with and without $\mathrm{SP}-\mathrm{C}^{1-35}$ ) on the Wilhelmy balance were similar under baseline conditions and in the presence of the inhibitor, but SP-B ${ }^{1-25}$ conferred more resistance against inhibition by fibrinogen than SP-B ${ }^{1-78}$ in the animals. Survanta ${ }^{\mathrm{TM}}$, containing smaller quantities of bovine SP-B/C, did poorly in the presence of fibrinogen in vitro, but was as effective as $\mathrm{B}^{1-}$ ${ }^{25}+\mathrm{C}^{1-35}$ surfactant in vivo, whereas $\mathrm{C}^{1-35}$ and PL surfactant were very sensitive to inhibition under both conditions.

Post mortem protein recovery from the airways exceeded that of the initial wash to establish surfactantdeficiency and the amount of fibrinogen administered intratracheally $\left(10 \mathrm{mg} \cdot \mathrm{kg}^{-1}\right)$. Without surfactant treatment, protein recovery from the airways in the final lavages was 10 times higher than in the first lavage. Surfactant treatment reduced the protein leakage during the experiment, with Survanta ${ }^{\mathrm{TM}}$ showing the greatest reduction in protein recovery. This indicates that in these surfactantdeficient rats, pretreated with intratracheal instillation of fibrinogen, protein leakage and lung injury progressed during the study period despite treatment with surfactant.

Fibrinogen was chosen as a surfactant inhibitor because of its great inhibitory capability in in vitro studies [9-11]. The present study started out with a fibrinogen dose based on an in vitro study using pulsating bubble surfactometry by SEEGER et al. [9], in which Survanta ${ }^{\mathrm{TM}}$ was inhibited in a dose-dependent manner by fibrinogen with a severe loss of surface activity at protein-surfactant ratios $>1$. However, high mortality among the lavaged rats (i.e. $80 \%$ mortality after $20 \mathrm{mg} \cdot \mathrm{kg}^{-1}$ of fibrinogen, $\mathrm{n}=5$ ) forced a decrease in the fibrinogen dose to $10 \mathrm{mg} \cdot \mathrm{kg}^{-1}$. This lower fibrinogen dose (with a fibrinogen to surfactant ratio of $1: 10$ ) was equally inhibitory on the surface balance.

Surfactant mixtures vary in their sensitivity to inhibitory plasma proteins, depending on differences in phospholipid composition and on the amount of SP-B present in the preparation [9]. In vitro studies have suggested that recombinant dipalmitoylated SP-C and short SP-C peptide sequences may be more sensitive to inhibition than natural surfactant proteins $[27,28]$. The authors also found the SP-C ${ }^{1-35}$ peptide, containing two palmitoylated cysteine residues, to be very sensitive to inhibition by fibrinogen in vitro and in vivo. A newer recombinant SP$\mathrm{C}$, containing phenylalanine instead of two cysteines in positions 4 and 5 of the human SP-C sequence and formulated in PL $(2 \% \mathrm{wt} / \mathrm{wt})$, was found to be at least as effective in a rat lung lavage model as bovine surfactants containing both SP-B and SP-C [29] and is currently tested in a multicentre trial for ARDS. Although surfactant inhibition plays a role in the pathogenesis of ARDS, this recombinant SP-C has not been tested for inhibition sensitivity. Use of a surfactant with SP-C as the only protein does not fit into the recent observation that SP-C knockout mice do not develop respiratory problems, whereas SP-B knockout mice die immediately after birth [30]. The in vitro and in vivo data, in this study, suggest that a mixture of surfactant lipids with SP-B ${ }^{1-25}$ (or SP-B ${ }^{1-78}$ ) and SP-C ${ }^{1-35}$ peptide is most effective in resisting inhibition by fibrinogen.

As expected, total phospholipid recovery from the airways was higher in the post mortem than in the initial lavage. Though only $15 \%$ of the instilled surfactant lipids was recovered in the post mortem lavage, there were no 
differences in recovery among the various surfactant preparations. This finding suggests that alveolar retention and/or metabolism of the various surfactant preparations used in this study does not differ. However, this would have to be confirmed by quantifying the presence of labelled surfactant components in the alveolar pool and lung tissue, which was not part of this study.

The present study shows that a relatively short surfactant protein B peptide, based on the N-terminal sequence of human surfactant protein $\mathrm{B}$, not only improves surface activity but can also confer effective resistance against inhibition by fibrinogen to a standard surfactant lipid mixture. The inhibition resistance conferred by $\mathrm{SP}-\mathrm{B}^{1-25}$ was at least similar or even better than the full-length SP$\mathrm{B}^{1-78}$ peptide or, in combination with SP-C ${ }^{1-35}$, the clinical surfactant Survanta ${ }^{\mathrm{TM}}$. SP-B ${ }^{1-25}$ peptide could therefore, potentially substitute full-length surfactant protein B in synthetic surfactant preparations.

\section{References}

1. Nogee LM, Garnier G, Dietz HC, et al. A mutation in the surfactant protein B gene responsible for fatal neonatal respiratory disease in multiple kindreds. $J$ Clin Invest 1994; 93: 1860-1863.

2. Robertson B, Kobayashi T, Ganzuka M, Grossmann G, Li WZ, Suzuki Y. Experimental neonatal respiratory failure induced by a monoclonal antibody to the hydrophobic surfactant-associated protein SP-B. Pediatr Res 1991; 30: 239-243.

3. Kobayashi T, Nitta K, Ganzuka M, Inui S, Grossmann G, Robertson B. Inactivation of exogenous surfactant by pulmonary edema fluid. Pediatr Res 1991; 29: 353-356.

4. Malloy J, McCaig L, Veldhuizen R, et al. Alterations of the endogenous surfactant system in septic adult rats. $\mathrm{Am}$ J Respir Crit Care Med 1997; 156: 617-623.

5. Holter JF, Weiland JE, Pacht ER, Gadek JE, Davis WB. Protein permeability in the adult respiratory distress syndrome. Loss of size selectivity of the alveolar epithelium. J Clin Invest 1986; 78: 1513-1522.

6. Holm BA, Notter RH, Finkelstein JN. Surface property changes from interactions of albumin with natural lung surfactant and extracted lung lipids. Chem Phys Lipids 1985; 38: 287-298.

7. Seeger W, Stöhr G, Wolf HRD, Neuhof H. Alteration of surfactantfunctionduetoproteinleakage:specialinteraction with fibrin monomer. J Appl Physiol 1985; 58: 326-338.

8. Holm BA, Notter RH. Effects of hemoglobin and cell membrane lipids on surfactant activity. J Appl Physiol 1987; 63: 1434-1442.

9. Seeger W, Grube C, Günther A, Schmidt R. Surfactant inhibition by plasma proteins: differential sensitivity of various surfactant preparations. Eur Respir J1993;6:971-977.

10. Manalo E, Merritt TA, Kheiter A, Amirkhanian J, Cochrane $\mathrm{C}$. Comparative effects of some serum components and proteolytic products of fibrinogen on surface tensionlowering abilities of beractant and a synthetic peptide containing surfactant KL4. Pediatr Res 1996; 39: 947-952.

11. Günther A, Bleyl H, Seeger W. Apoprotein-based synthetic surfactants inhibit plasmic cleavage of fibrinogen in vitro. Am J Physiol 1993; 265: L186-L192.

12. Holm BA, Wang Z, Notter RH. Multiple mechanisms of lung surfactant inhibition. Pediatr Res 1999; 46: 85-93.

13. Mbagwu N, Bruni R, Hernandez-Juviel JM, Waring AJ, Walther FJ. Sensitivity of synthetic surfactants to albumin inhibition in preterm rabbits. Mol Genet Metab 1999; 66: $40-48$.
14. Waring A, Taeusch W, Bruni R, Amirkhanian J, Fan B, Stevens R, Young J. Synthetic amphipathic sequences of surfactant protein-B mimic several physicochemical and in vivo properties of native pulmonary surfactant proteins. Peptide Res 1989; 2: 308-313.

15. Bruni R, Taeusch HW, Waring AJ. Surfactant protein B: lipid interactions of synthetic peptides representing the amino-terminal amphipathic domain. Proc Natl Acad Sci USA 1991; 88: 7451-7455.

16. Longo ML, Bisagno AM, Zasadzinski JA, Bruni R, Waring AJ. A function of lung surfactant protein SP-B. Science 1993; 261: 453-456.

17. Gordon LM, Lee KYC, Lipp MM, et al. Conformational mapping of the $\mathrm{N}$-terminal segment of surfactant protein $\mathrm{B}$ in lipid using ${ }^{13} \mathrm{C}$-enhanced Fourier transform infrared spectroscopy. J Pept Res 2000; 55: 330-347.

18. Fields CG, Loyd DH, McDonald RL, Ottenson KM, Nobel RL. HBTU activation for automated Fmoc solidphase peptide synthesis. Peptide Res 1991; 4: 95-101.

19. Lipp MM, Lee KYC, Zasadzinski JA, Waring AJ. Phase and morphology changes in lipid monolayers induced by SP-B protein and its amino terminal peptide. Science 1996; 273: 1196-1199.

20. Walther FJ, Hernandez-Juviel J, Bruni R, Waring AJ. Spiking Survanta ${ }^{\mathrm{TM}}$ with synthetic surfactant peptides improves oxygenation in surfactant-deficient rats. $\mathrm{Am} J$ Respir Crit Care Med 1997; 156: 855-861.

21. Gordon LM, Horvath S, Longo ML, et al. Conformation and molecular topography of the N-terminal segment of surfactant protein B in structure-promoting environments. Protein Science 1996; 5: 1662-1675.

22. Walther FJ, Hernandez-Juviel J, Bruni R, Waring AJ. Protein composition of synthetic surfactant affects gas exchange in surfactant-deficient rats. Pediatr Res 1998; 43: 666-673.

23. Mizuno K, Ikegami M, Chen $\mathrm{CM}$, Ueda $\mathrm{T}$, Jobe $\mathrm{AH}$. Surfactant protein-B supplementation improves in vivo function of a modified natural surfactant. Pediatr Res 1995; 37: 271-276.

24. Walther FJ, David-Cu R, Leung C, et al. A synthetic segment of surfactant protein A: structure, in vitro surface activity, and in vivo efficacy. Pediatr Res 1996; 39: 938-946.

25. Markwell MA, Haas SM, Bieber LL, Tolbert NE. A modification of the Lowry procedure to simplify protein determinations in membrane and lipoprotein samples. Anal Biochem 1978; 87: 206-210.

26. Dittmer JC, Wells MA. Quantitative and qualitative analysis of lipids and lipid components. Methods Enzymol 1969; 14: 482-530.

27. Seeger W, Thede C, Gunther A, Grube C. Surface properties and sensitivity to protein-inhibition of a recombinant apoprotein $\mathrm{C}$-based phospholipid mixture in vitro - comparison to natural surfactant. Biochim Biophys Acta 1991; 1081: 45-52.

28. Amirkhanian JD, Bruni R, Waring AJ, Taeusch HW. Inhibition of mixtures of surfactant lipids and synthetic sequences of surfactant proteins SP-B and SP-C. Biochim Biophys Acta 1991; 1096: 355-360.

29. Häfner D, Germann P-G, Hauschke D. Effects of rSP-C surfactant on oxygenation and histology in a rat-lunglavage model of acute lung injury. Am J Respir Crit Care Med 1998; 158: 270-278.

30. Clark JC, Wert SE, Bachurski CJ, et al. Targeted disruption of the surfactant protein $\mathrm{B}$ gene disrupts surfactant homeostasis, causing respiratory failure in newborn mice. Proc Natl Acad Sci USA 1995; 92: 7794-7798. 